\section{Prevention of urinary retention with phenoxybenzamine during epidural morphine}

Since the first reports by Wang and Behar and others the use of epidural and intrathecal opiates for pain relief has become widely accepted. The most common and distressing complication of this mode of analgesia is acute urinary retention, which occurs in $3 \%^{1}$ to $100 \%{ }^{2}$ of patients. We studied the postoperative urinary complications in a group of patients who underwent elective caesarean section under epidural anaesthesia and who received epidural morphine for postoperative pain relief. In addition, the efficacy of the alpha adrenergic blocking agent phenoxybenzamine (Dibenyline) in alleviating postoperative micturition difficulties and urinary retention was investigated.

\section{Methods and results}

After giving informed consent, 60 patients aged 23-42 years were divided at random into two equal groups. All were injected with $20 \mathrm{ml}$ bupivacaine $0.5 \%$ via a Tuohy needle inserted epidurally into the L1-2 or L2-3 interspace. An indwelling catheter was then placed caudally. At the end of surgery a single dose of $4 \mathrm{mg}$ morphine hydrochloride diluted in $10 \mathrm{ml}$ isotonic saline without preservative was injected through the epidural catheter for postoperative analgesia. In addition, the 30 patients in group 2 received four oral doses of $10 \mathrm{mg}$ phenoxybenzamine 24 and two hours before and eight and 16 hours after surgery. Except for the epidural morphine no opiates were given to either group. A non-narcotic drug ( $1000 \mathrm{mg}$ dipyrone intramuscularly or by mouth), however, was dispensed freely on request. The same amount of postoperative fluid (2.5-3.01 Hartman's solution) was administered to both groups. The patients were closely observed for 48 hours. Medical staff did not know which of the patients had been given phenoxybenzamine. Difficulty in micturition, volumes of the first two voidings after operation, the time intervals between the end of surgery and first micturition, urinary tract infection, and urinary retention were noted. For this investigation we designated "urinary retention" as discomfort and sensation of a full bladder or a palpable distended bladder. In such instances the patient was encouraged to void. If urine was not passed spontaneously after one hour the bladder was catheterised.

From the volumes of the two initial urine voidings and the time interval between the end of the operation and first micturition phenoxybenzamine clearly alleviated or prevented difficulties in micturition and urinary retention (table). In group 1, 26 patients complained of difficulty in micturition, whereas in group 2 only two patients did so. The overall rate of urinary retention diminished from $46.6 \%$ (14 patients) in group 1 to $10 \%$ (three patients) in group 2, while the need for bladder catheterisation decreased from $53.3 \%$ (16 patients) to $10 \%$ (three patients). Urinary tract infections occurred in three patients in group 1 and in none of the patients in group 2 . Oral phenoxybenzamine given during epidural analgesia was not associated with hypotension or with any other untoward effect.

\section{Comment}

The nervous control of the urinary bladder is complex and the exact role of the sympathetic system in normal micturition is difficult to define. It has been suggested ${ }^{3}$ that bladder overdistension as occurs during regional anaesthesia enhances alpha adrenergic sympathetic activity, thereby increasing the closure pressure of the urethral sphincter, which, in turn, leads to difficulty in micturition. The same chain of reactions is caused by the stress of anaesthesia and surgery owing to the increased secretion of adrenaline. Under these circumstances administration of an alpha adrenergic blocking agent should diminish effectively the difficulty in micturition. ${ }^{3}$

The exact mechanism of epidural morphine in causing urinary retention is not known. It may be due to the effect on the tone of the internal urethral sphincter, ${ }^{1}$ to the influence of the parasympathetic outflow from the sacral cord, ${ }^{4}$ or to a local anaesthetic effect on bladder innervation. According to Petersen et al, ${ }^{5}$ the effect of morphine on the urinary bladder is peripheral, and this was supported by other workers. ${ }^{2}$
Most of our patients benefited from phenoxybenzamine. We therefore recommend it as an effective and safe drug for alleviating or preventing urinary complications in patients receiving epidural morphine for pain relief.

${ }^{1}$ Magora F, Olshwang D, Emierl D, et al. Observations on extradural morphine analgesia in various pain conditions. $B r \mathcal{F}$ Anaesth 1980;52: 247-52.

2 Weddel SJ, Ritter RR. Serum levels following epidural administration of morphine and correlation with relief of postsurgical pain. Anesthesiology $1981 ; 54: 210-4$.

${ }^{3}$ Caine M, Pfau A, Perlberg S. The use of alpha adrenergic blockers in benign prostatic obstruction. Br J Urol 1976;48:255-63.

${ }^{4}$ Yaksh TL. Spinal opiate analgesia: characteristics and principles of action. Pain 1981;11:293-346.

${ }^{5}$ Petersen TK, Husted SE, Rybro L, Schurizek BA, Wernberg M. Urinary retention during IM and extradural morphine analgesia. $B r f$ Anaesth $1982 ; 54: 1175-7$.

(Accepted 23 September 1983)

Hadassah University Hospital, Jerusalem, Israel

SAMUEL EVRON, MD, senior in anaesthesia, senior resident in obstetrics and gynaecology

FLORELLA MAGORA, MD, professor of anaesthesiology

ELIAHU SADOVSKY, MD, professor of obstetrics and gynaecology

Correspondence to: Dr Samuel Evron, Department of Obstetrics and Gynaecology, Hadassah University Hospital, PO Box 12000, Jerusalem, Israel 91120.

\section{Resolution of salmonella carriage after duodenoscopic treatment for a common bile duct stone}

Less than $3 \%$ of patients infected with Salmonella typhi, and probably even fewer with other salmonella organisms, become chronic carriers. Most of those who do have gall bladder stones; antibiotic treatment alone is effective in about two thirds of cases. If surgical treatment is indicated (because of occupation or important biliary symptoms), cholecystectomy cures about $85 \%$ of patients. ${ }^{1}$ We report an apparently unique case of a patient with chronic carriage of an unusual organism (Salmonella eastbourne) who was cured by removal of a bile duct stone 18 years after cholecystectomy.

\section{Case report}

A 70 year old woman was referred for endoscopic management of recurrent cholestasis attributed to common bile duct stones. She had had a cholecystectomy for gall stones 18 years before (without exploration of the common bile duct) and then remained well until the three years before referral; since then she had required admission on four occasions for recurrent jaundice. Each illness was managed conservatively, the condition resolving over a few days. A stool specimen six months before referral had grown $S$ eastbourne, and subsequent cultures remained positive despite the use of gentamicin and cephradine (to which the organism was sensitive) in the management of her biliary disease.

Endoscopic retrograde cholangiography showed a $4 \times 1.5 \mathrm{~cm}$ stone in a dilated common bile duct. Duodenoscopic sphincterotomy was performed but an initial attempt to remove the stone was unsuccessful. Culture of stool and bile yielded $S$ eastbourne. A nasobiliary catheter was placed to promote drainage $^{2}$ and infuse the duct with mono-octanoin in an attempt to reduce the size of the stone. ${ }^{3}$

After three days' infusion she developed biliary pain accompanied by

Postoperative urinary complications in the two groups of patients studied

\begin{tabular}{|c|c|c|c|c|c|c|c|}
\hline Group & $\begin{array}{c}\text { Mean (SD) volume } \\
\text { of first } \\
\text { voiding }(\mathrm{ml})\end{array}$ & $\begin{array}{l}\text { Mean }(\mathrm{SD}) \text { volume } \\
\text { of second } \\
\text { voiding }(\mathrm{ml})\end{array}$ & $\begin{array}{c}\text { Mean (SD) delay } \\
\text { to first } \\
\text { voiding (hours) }\end{array}$ & $\begin{array}{l}\text { No (") of patients } \\
\text { with difficulty } \\
\text { in micturition }\end{array}$ & $\begin{array}{c}\text { No ("i) of patients } \\
\text { with } \\
\text { urinary retention }\end{array}$ & $\begin{array}{l}\text { No }(\%) \text { of patients } \\
\text { with } \\
\text { catheterisation }\end{array}$ & $\begin{array}{c}\text { No }(\%) \text { of patients } \\
\text { with } \\
\text { urinary infection }\end{array}$ \\
\hline $\begin{array}{l}1(\mathrm{n}=30) \\
2(\mathrm{n}=30)^{*}\end{array}$ & $\begin{array}{l}250.0(155.9) \\
478.3(186.6)\end{array}$ & $\begin{array}{l}237.5(114.7) \\
416.6(179.8)\end{array}$ & $\begin{array}{l}9 \cdot 7(2.9) \\
5.3(1.5)\end{array}$ & $\begin{array}{r}26(86 \cdot 6) \\
2(6 \cdot 6)\end{array}$ & $\begin{array}{r}14(46 \cdot 6) \\
3(10 \cdot 0)\end{array}$ & $\begin{array}{r}16(53 \cdot 3) \\
3(10.0)\end{array}$ & $\begin{array}{l}3(10 \cdot 0) \\
0\end{array}$ \\
\hline
\end{tabular}

*Given phenoxybenzamine in addition to epidural morphine. 